\title{
Alina Brzuska-Kępa
}

Katedra Informatologii i Bibliologii

Uniwersytet Łódzki

e-mail: alinabrzuska@poczta.onet.pl

\section{Rafał Kępa}

Katedra Informatologii i Bibliologii

Uniwersytet Łódzki

e-mail: rafalmkepa@poczta.onet.pl

\section{„Zilustrować niewysławialne” - o obrazach w filozoficznych picturebookach dla dzieci}

\section{DOI: http://dx.doi.org/10.18778/0860-7435.22.23.04}

\begin{abstract}
Abstrakt: W ostatnich latach na rynku księgarskim pojawia się coraz więcej przeznaczonych dla dzieci książek filozoficznych, bądź przynajmniej "filozofujących”. Duża część publikacji tego typu to picturebooki, posługujące się obrazem jako głównym nośnikiem informacji. W niniejszym artykule spróbujemy odpowiedzieć na pytanie, czy konstruowanie treści w oparciu nie tylko o tekst, ale i o równie istotny obraz może być pomocne w przedstawieniu pojęć abstrakcyjnych. W jaki sposób autorzy i ilustratorzy próbują prezentować najbardziej ogólne, a zarazem najtrudniejsze zagadnienia filozoficzne? Czy posługiwanie się obrazem jest w tym przypadku ułatwieniem, czy też może to, co "niewysławialne”, jest zarazem „nieilustrowalne”?
\end{abstract}

Słowa kluczowe: picturebook, książka filozoficzna dla dzieci, obraz, ilustracja, przekład intersemiotyczny 


\section{Alina Brzuska-Kępa, Rafał Kępa}

„O czym nie można mówić, o tym trzeba milczeć” (Wittgenstein, 2016, s. 3) - zanim Ludwig Wittgenstein zawarł w wydanym w roku 1921 Traktacie logiczno-filozoficznym to znaczące napomnienie, ludzkość zdążyła napisać i opublikować całe tomy dzieł o tym, co niewypowiedziane, a przynajmniej trudne do wypowiedzenia: nazwania, określenia, zdefiniowania. Taki charakter ma chociażby pojęcie bytu, centralne dla arystotelesowskiej Metafiøyki (oraz setek innych, nawiązujących do niej dzieł), o którym sam Stagiryta twierdził, że, jako najbardziej ogólne, jest zarazem niedefiniowalne. Jeśli więc nie mamy dobrej definicji tego, co - zdawać by się mogło - najbardziej oczywiste, o ile trudniej będzie zdefiniować jego przeciwieństwo: niebyt, nic. Podobnie trudne może być opisanie wartości. Wiemy mniej więcej, co jest dobre, sprawiedliwe, piękne - lecz czym jest (o ile w ogóle w jakiś sposób „jest”) dobro, sprawiedliwość czy piękno'? Wydaje się, że wbrew dość zdroworozsądkowej tezie Wittgensteina, filozofia, zarówno przed nim, jak i po nim, nie potrafi obyć się bez tego typu pojęć ogólnych.

W ostatnich latach na rynku księgarskim pojawia się coraz więcej przeznaczonych dla dzieci książek filozoficznych, bądź przynajmniej „,filozofujących"”2. Duża część publikacji tego typu to picturebooki, posługujące się obrazem jako głównym nośnikiem informacji ${ }^{3}$. W niniejszym artykule spróbujemy

\footnotetext{
${ }^{1}$ Dyskusje na ten temat, zwane sporem o uniwersalia, zapoczątkowane zostały już w starożytności. Szczególnie żywiołowe stały się w średniowieczu, toczą się zaś w środowisku filozofów i matematyków do dziś; zob. np. (Murawski, 2001, s. 176-181).

${ }^{2}$ Wedle rozumienia zaproponowanego w: (Kępa, 2013, s. 349) pierwszym mianem nazwać należałoby publikacje filozoficzne sensu stricto, poświęcone filozofii i filozofom, podobne do swego rodzaju jej „powieściowego podręcznika” dla dzieci i młodzieży - Świata Zofii Josteina Gaardera (1995). W przypadku książek, które zostaną opisane w niniejszym artykule, bardziej adekwatne byłoby określenie „filozofujące” - czyli takie, które nie odnoszą się do królowej nauk wprost, ale stawiają te same pytania, jakie podejmowali od czasów Talesa z Miletu miłośnicy mądrości: o istnienie i początki świata, o przeznaczenie i sens życia ludzkiego, o istnienie świata transcendentnego, nadprzyrodzonego (Boga, nieba itp.), o rzeczy ostateczne - śmierć i życie po niej (jakiejkolwiek formy miałoby ono nie przybierać), wreszcie o wartości, szczególnie moralne.

3 Współcześnie pod nazwą książki obrazkowej czy obrazowej rozumie się nie tylko książkę z obrazkami lub ilustrowana, w których obraz jest bądź uzupełnieniem tekstu, bądź unaocznieniem prowadzonej narracji. Niektórzy - jak choćby Uri Shulevitz i Kenneth Marantz kładą nacisk na znaczenie obrazu i umiejscawiają książkę obrazkową wśród sztuk wizualnych, zaznaczając, że dzieci przyswajają historie opowiedziane zarówno wizualnie, jak i werbalnie, stąd „książki obrazkowe są całkiem efektywne bez żadnych słów” (Kiefer, 2008, s. 10). W większości ustaleń teoretycznych, książka obrazkowa pojmowana jest dziś jako artefakt zakładający równoważne funkcjonowanie w nim dwu kodów przekazu: językowego i ikonograficznego. Maria Nikolajeva i Carole Scott (2006, s. 1-2) podkreślają wyjątkowość tak pojmowanej książki obrazkowej i posiłkując się terminologia semiotyczną zakładają, że picturebook komunikuje przez dwie oddzielne sieci znaków - ikonicznych i konwencjonalnych,
} 


\section{„Zilustrować niewysławialne”...}

odpowiedzieć na pytanie, czy przyjęcie takiej konwencji - to jest konstruowanie treści w oparciu nie tylko o tekst, ale i o równie istotny obraz (niekiedy sporządzany przez tę samą osobę) - może być pomocne w przedstawieniu wspomnianych wyżej „niewysłowionych” pojęć. W jaki sposób autorzy i ilustratorzy próbuja prezentować te najbardziej ogólne, a zarazem najtrudniejsze zagadnienia? Czy posługiwanie się obrazem jest $\mathrm{w}$ tym przypadku ułatwieniem, czy też może to, co „niewysławialne”, jest zarazem „nieilustrowalne”?

Nie będziemy pisali o pojęciach tak ogólnych jak sam byt ${ }^{4}$. Spróbujemy natomiast pokazać na wybranych przykładach, w jaki sposób obrazowane sa zagadnienia o naturze eschatologicznej: śmierć i życie wieczne (Gibert, 2011; Erlbruch, 2008). Przyjrzymy się artystycznej wizji początków wszechświata (Moyeart \& Erlbruch, 2005). Na podstawie czterech publikacji przedstawimy sposób ilustrowania losu i sensu życiu ludzkiego (Erlbruch, 2006; Cali \& Bloch, 2013; Chmielewska, 2013; Halling \& Eriksson, 2010). Książka Halling i Eriksson, podobnie jak nie wydana do tej pory w Polsce $W$ połowie pusta, w połowie pełna Iwony Chmielewskiej (Chmielewska, 2008) posłużą do pokazania, jak prezentowane są wartości - szczególnie ich relatywny charakter.

Niebo Bruno Giberta (2011) jest bardzo ciekawa realizacja pierwszego ze wspomnianych wyżej tematów. Nie mówi się w niej wprawdzie wprost o Bogu, być może ze względu na swego rodzaju uniwersalny czy ponadreligijny jej charakter (o czym będzie jeszcze za chwilę mowa), próbuje ona jednak opisać stan, w jakim, wedle wierzeń, znajduje się człowiek po swej śmierci. Kres życia ukazany jest jako początek kolejnego, następującego po przejściu zmarłego do nowej, duchowej rzeczywistości. W taki sposób, pamiętając, rzecz jasna, o różnicach dotyczących konkretnych wyobrażeń, rozumie się życie po śmierci w trzech wielkich religiach światowych: judaizmie, chrześcijaństwie i islamie. Nieco inną (mniej osobowa) formę bytowania uznaje się także w buddyzmie i hinduizmie. W ksiazżce B. Giberta niebo to miejsce, do którego miał być zabrany po swej śmierci dziadek małego narratora książki (Tamże, s. 4). Wizja nieba przedstawiona w książce nie jest, jak już wspomniano, związana z konkretną religia, została wyrażona w sposób uniwersalny. Stanowi swego rodzaju kompendium podstawowych wierzeń dotyczących życia po śmierci. Warto zaznaczyć, że ten

których funkcja jest przedstawianie i narracja. Perry Nodelman (1988, s. 222) twierdzi, że związek obrazu i tekstu jest zawsze dość ironiczny: „słowa mówią nam to, czego nie pokazuja obrazy, zaś obrazy pokazuja to, czego słowa nie mówią...”. Czyż nie jest to jednak sytuacja idealna dla prób przekazania i opisania tego, co, jak w przypadku naszych pojęć filozofujących, jest abstrakcyjne i językowo „niedookreślalne”?

${ }^{4}$ Te raczej rzadko pojawiają się w publikacjach dla najmłodszych; warto niemniej wspomnieć, że istnieje dobra książka poświęcona niebytowi - Nic Marii Marjańskiej-Czernik z ilustracjami Krystyny Lipki-Sztarbałło (Marjańska-Czernik \& Lipka-Sztarbałło, 2008). 


\section{Alina Brzuska-Kępa, Rafał Kępa}

uniwersalny charakter podkreślony jest także poprzez dobór formy graficznej ilustracji (czy raczej obrazów, jako że mamy do czynienia z książką obrazowa $)^{5}$. Wszystkie one mają bowiem postać piktogramów, a zatem, wedle ujęcia Teresy Tomaszkiewicz, schematycznych, realistycznych lub symbolicznych rysunków, oddających sens komunikatu językowego bez pośrednictwa języka. W tym przypadku przekaz zostaje zakodowany przy użyciu środków zaczerpniętych z systemu wizualnego (2009, s. 51).

Istotną cechą piktogramów jest ich umowność; ich treści są „utarte” i znane (przynajmniej w pewnej grupie społecznej). Każdy piktogram jest monosemiczny, a więc jednoznacznie wiązany z jednym, określonym znaczeniem (Tamże, s. 52). Najistotniejsza, jak się wydaje, funkcją piktogramu jest właśnie upowszechnienie treści, realizowane dzięki zastappieniu słowa w określonym języku, dostępnego tylko dla posługujących się nim osób, powszechnie rozumianym obrazem. Ma to szczególną wartość zwłaszcza w przypadku pojęć abstrakcyjnych, ze swej natury trudnych do zdefiniowania. Rozwiązanie przyjęte przez autora jest zatem znakomitym sposobem uprzystępnienia młodemu czytelnikowi tego, co w inny sposób mogłoby być trudne do zrozumienia, choć trzeba zarazem przyznać, że posługując się piktogramami, Gibert traktuje je w sposób dość szczególny, o czym będzie jeszcze mowa nieco później.

Przyjrzyjmy się kilku przykładom. U B. Giberta niebo - cel podróży, jaka jest życie - oznaczone jest na stronie tytułowej znakiem informacyjnym „parking” (Gibert, 2011, s. 3). „Pójście do nieba” zobrazowano natomiast za pomoca znaku drogowego „lotnisko” (Tamże, s. 5). Warto dodać, że za pomoca piktogramów zilustrowane są w książce nie tylko treści abstrakcyjne, ale i całkiem konkretne. Dla przykładu, zdanie „Mój kochany dziadziuś nie był aż tak stary, żeby iść do nieba", połączył autor z obrazem przedstawiającym znak określający dopuszczalna prędkość $60 \mathrm{~km}$ na godzinę. W tym przypadku odnosi się on zapewne do nieprzekroczonego wieku 60 lat (Tamże, s. 12-13).

Niebo przedstawione jest w książce B. Giberta jako miejsce, w którym „podobno [zwróćmy uwage na hipotetyczny tryb wypowiedzi] jest dobrze, sa tam wszystkie współczesne wygody". Zdanie to zilustrowane zostało za pomocą zestawu znaków informacyjnych, określających listę udogodnień oferowanych, na przykład w przydrożnym hotelu (Tamże, s. 15).

\footnotetext{
${ }^{5}$ Warto wspomnieć, że Bruno Gibert jest autorem zarówno tekstu, jak i ilustracji Nieba.
} 


\section{„Zilustrować niewysławialne"...}

Rys. 1. Podobno w niebie jest dobrze...

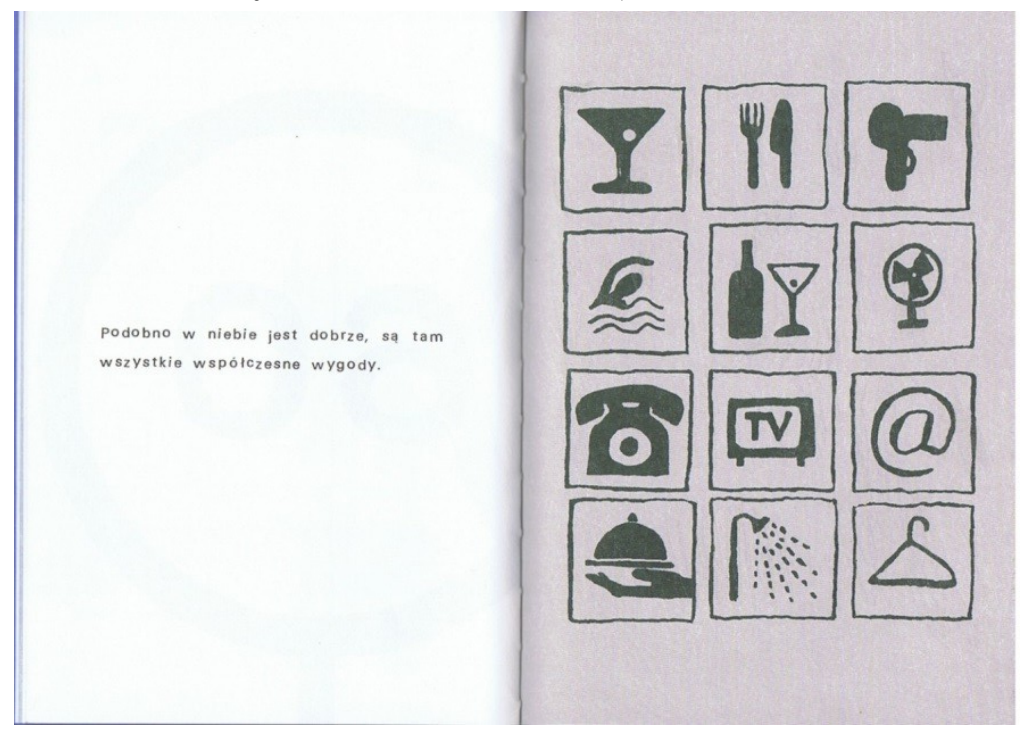

Źródło: Gibert, 2011, s. 15.

Uniwersalny, panreligijny charakter przekazu książki bardzo wyraźnie odzwierciedlaja słowa: „wszyscy idą do nieba”, uzupełnione ilustracja przedstawiająca symbole wielkich religii (islamu, judaizmu, taoizmu i chrześcijaństwa), rozumiejących niebo właśnie jako stan szczęśliwości, który można osiagnąć po zakończeniu życia ziemskiego, bądź po prostu przyszłą, duchową formę życia (Tamże, s. 24-25).

Alternatywą dla tak rozumianego „nieba” jest reinkarnacja, w którą wierzą wyznawcy buddyzmu. B. Gibert pisze o niej w następujący sposób: „Niektórzy myślą, że po śmierci rodzimy się na nowo w jakiejś innej postaci”, zaś słowom tym towarzyszy symbol recyklingu (Tamże, s. 34-35).

Tym, co jednak dla narratora najważniejsze, jest wynikające $z$ wiary w życie pozagrobowe poczucie bliskości zmarłego dziadka. „Czuję, jakby był tu, całkiem blisko, i można było z nim porozmawiać" - mówi; słowa te zostały uzupełnione przez piktogram przedstawiający słuchawkę telefonu, powszechnie zrozumiały symbol oznaczający możliwość komunikowania się oddalonych od siebie osób (Tamże, s. 45).

Warto w tym miejscu dodać, że B. Gibert w swoisty sposób redefiniuje używane piktogramy; nadaje im nowe sensy. Coś bardzo materialnego i na trwałe - wydawać by się mogło - związanego ze ściśle określonym znaczeniem, wpisuje w sferę eschatologii, odnosząc do treści wykraczających poza doczesność: przemijanie, śmierć, życie po śmierci, raj. W tych nowych funk- 


\section{Alina Brzuska-Kępa, Rafał Kępa}

cjach występuja one tylko $\mathrm{w}$ powiązaniu $\mathrm{z}$ tekstem. Bez niego wróciłyby w sposób naturalny i nieunikniony do swych pierwotnych znaczeń.

Równie ciekawą realizacją tematu śmierci i tego, co następuje po niej, jest książka Gés, śmierć $i$ tulipan (Erlbruch, 2008) ${ }^{6}$. Podobnie jak w Niebie, pojawiają się tutaj przypuszczenia dotyczące ewentualnego życia po śmierci, maja jednak charakter zdecydowanie bardziej hipotetyczny. Narrator Nieba z dużym przekonaniem twierdzi, że wszyscy idą do nieba (Gibert, 2011, s. 24). Oprócz przypuszczeń („Podobno w niebie jest dobrze, sa tam wszystkie współczesne wygody" - Tamże, s. 14) pojawiają się także stwierdzenia bardziej kategoryczne („Na pewno trochę, tak koło południa” - Tamże, s. 20). W książce Wolfa Erlbrucha mamy do czynienia właściwie wyłącznie z domniemaniami, choć jedną z jej bohaterek jest śmierć, mogłoby się więc wydawać, że nikt nie wie lepiej od niej, co jest „po drugiej stronie”. Tymczasem śmierć, odpowiadając na pytanie, czy zmarłe gęsi zamieniają się w anioły, odpowiada jedynie: „Bardzo możliwe [...] W każdym razie skrzydła już macie” (Erlbruch, 2008, s. 16). Podczas tej samej rozmowy w następujący sposób komentuje słowa ptaka o istnieniu piekła, w którym „smażą się złe gęsi”: „Nie do wiary, co wy [...] sobie opowiadacie, ale kto wie" (Tamże, s. 17).

W warstwie ikonograficznej książka jest niezwykle prosta, wręcz minimalistyczna. Autor kreśli je za pomoca prostej kreski, z użyciem dość ubogiej palety stonowanych, mało nasyconych kolorów (dominują beże i szarości). $\mathrm{Na}$ większości obrazów widzimy jedynie tytułowe postaci (gęś i śmierć), z pominięciem drugiego planu, a często nawet tła. Z konieczności zatem brakuje też perspektywy, obrazy sa płaskie, dwuwymiarowe.

Najciekawszy jest jednak sposób zobrazowania śmierci. Ma ona postać upersonifikowaną $\mathrm{i}$ w pewnym stopniu tradycyjną: ludzkiego szkieletu. Jest jednak ubrana w długa suknię w czerwoną kratę i kraciasty płaszcz koloru szarego. Właściwie jedynym widocznym elementem szkieletu jest czaszka z wyraźnie zarysowanymi oczodołami i otworem nosowym. Stopy śmierci zakrywaja płaskie, pozbawione obcasów buty. Nawet dłonie, które widoczne są spod rękawów płaszcza, nie przypominają kościstych kończyn tradycyjnie wyobrażanej kostuchy; wyglądają raczej, jakby okrywały je ciemne, jednopalczaste rękawice. To wszystko pozbawia ją grozy, jaką wywoływać ma większość jej przedstawień. Przeciwnie - śmierć z książki Erlbrucha wydaje się miła, przyjazna. Zaznaczono to także w warstwie tekstowej; w pewnym momencie narracji padają słowa: „Właściwie była miła, a jeśli zapomnieć o tym, KIM była - nawet bardzo miła" (Erlbruch, 2008, s. 10). W wielu miejscach zarówno sposób ułożenia „ciała” (lekkie ugięcie kolan na stronie 5., wysunięta

\footnotetext{
${ }^{6}$ Interpretację tego tekstu znajdzie czytelnik np. w: (Kępa, 2013).
} 


\section{„Zilustrować niewysławialne”...}

stopa na stronie 6., swobodny, niedbały sposób siedzenia na stronie 15 . i leżenia na 14., trzymanie gęsi za „ręce” - a właściwie skrzydła - na stronie 25.), jak i wspomniany już ubiór, sprawiają wrażenie, że mamy do czynienia z małą dziewczynką. Jest ono potęgowane poprzez ukazywanie gęsi i śmierci w kojarzących się z zabawą okolicznościach: pływających w stawie (s. 12) czy skrywających się w koronie drzewa (s. 21 i 22). Także wspomniane już złączone ręce (s. 25) przywodzą na myśl dziecięcy taniec, np. powszechnie znane „kó1ko graniaste". Oczywiście, gest ten nawiązuje także do znanego motywu tańca śmierci ${ }^{7}$, niemniej, w świetle tego, co zostało powiedziane, także i on został mocno przetworzony. Wizerunek śmierci z książki W. Erlbrucha pozbawiony jest grozy właściwej większości przedstawień danse macabre.

Rys. 2. Śmierć i gęś trzymające się za „ręce”

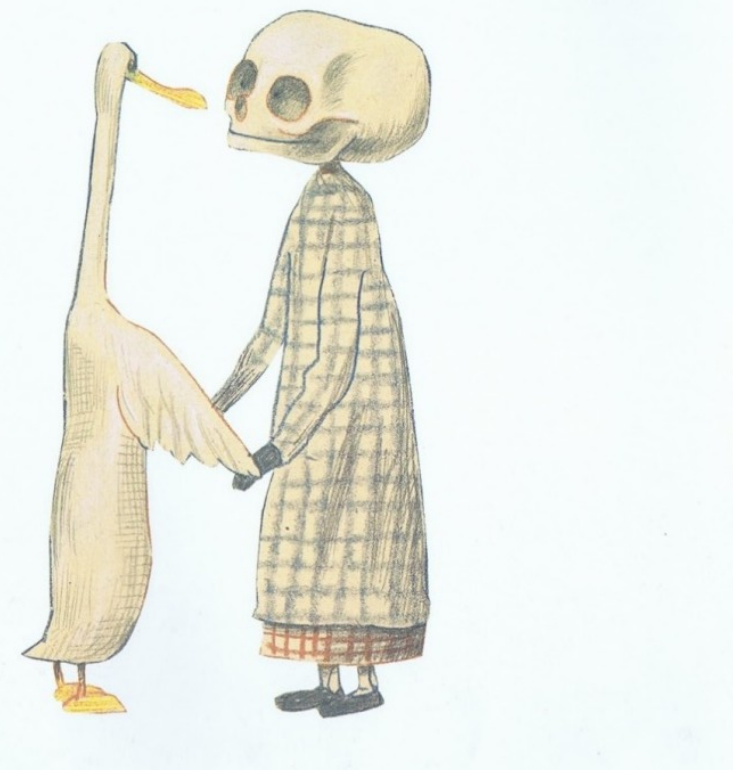

Źródto: Erlbruch, 2008, s. 25.

W kluczowym momencie narracji (kiedy gęś umiera) śmierć wraca jednak do swej „poważnej” roli. Pochyla się z troską nad umierającą (s. 27). Bierze bezwładne ciało na ręce i ostrożnie niesie nad rzekę (co ciekawe, trzymany przez nią na wielu obrazkach czarny tulipan tym razem niesie - ponieważ ma zajęte obie ręce - w zębach: s. 28). Kładzie ostrożnie zwłoki gęsi na wodzie

\footnotetext{
${ }^{7}$ Szerzej o danse macabre zob. m. in.: Schuster, 2002; Lurker, 2004, s. 345 i następne; Oesterreicher-Mollwo, 1992, s. 156.
} 


\section{Alina Brzuska-Kępa, Rafał Kępa}

i, ułożywszy uprzednio tulipan na jej brzuchu, popycha delikatnie, po czym patrzy na nia, dopóki nie straci jej z oczu (s. 29, 30). Wtedy - pisze narrator „Prawie zrobiło się jej smutno. Ale takie było życie” (s. 30).

Warto dodać, że W. Erlbruch odwołuje się w omówionych wyżej przedstawieniach do powszechnie znanej symboliki. Gęś jest w tradycji celtyckiej (podobnie jak łabędź) odpowiednikiem duszy, łącznikiem pomiędzy światem cielesnym i duchowym (Oesterreicher-Mollwo, 1992, s. 44-45 i 88-89; Cirlot, 2006, s. 136). Rzeka w wielu kulturach symbolizuje upływ, przemijanie - także śmierć (Cirlot, 2006, s. 359; Lurker, 1994, s. 320-321). Tulipan oznacza miłość, w połączeniu z czarnym kolorem - sięgająca po kres życia bądź związaną z jego poświęceniem (Lurker, 1994, s. 239).

Stworzenie Barta Moyearta (Moyeart \& Erlbruch, 2005), książka zilustrowana przez Wolfa Erlbrucha, jest ciekawą realizacja zagadnienia bytu transcendentnego - Boga. Nie skupia się jednak na jego naturze, lecz raczej koncentruje się na jego roli w powstaniu świata. Inaczej niż Niebo, posiadające wyraźnie uniwersalny charakter, Stworzenie reprezentuje określony pogląd na omawiane zagadnienie. Artystyczna wizja autora jest zasadniczo zgodna z chrześcijańską koncepcją stworzenia. Jedynym, choć dość istotnym odstępstwem od przekazu biblijnego jest uczynienie z pierwszego człowieka, Adama - obserwatora całego procesu, jeśli nie współwiecznego Stwórcy, to przynajmniej wcześniejszego od wszelkiego stworzenia. Nie pasuje to do żadnego z dwóch opisów powstania świata zawartych w Księdze rodzaju (Rdz. 1, 1-31, 2, 1-3; Rdz. 2, 4b-7). Wszystko inne jednak już się zgadza. Świat na przykład zostaje stworzony z niczego, powołany do istnienia z niebytu, dlatego też Bóg i Adam siedzą (jeszcze przed początkiem) na krzesełkach zawieszonych w pustce, nicości - poza nimi nie ma jeszcze nic (Tamże, s. 7). Proces stworzenia odbywa się w czasie, w ciagu kilku dni, zaś kolejność powstających rzeczy (poza wspomnianym wyjątkiem Adama) ściśle odpowiada opisowi biblijnemu.

Obraz Boga w Stworzeniu jest antropomorficzny i, rzec można, tradycyjny: jest to po prostu brodaty staruszek w długiej szacie. Zarówno jednak bardzo prosta kreska, jaką został narysowany, jak i gestykulacja i mimika stwórcy pozbawiaja go wyniosłości, charakterystycznej dla wielu przekazów religijnych. Patrząc na uśmiechniętego Boga, unoszącego kciuk w geście aprobaty (Tamże, s. 10) ${ }^{8}$, a nawet huśtającego się radośnie na gałęzi dopiero co stworzonego drzewa (Tamże, s. 24), nie możemy wattpić, że mamy do czynienia z Bogiem dobrym, który tworzy świat dla człowieka i z miłości do niego.

\footnotetext{
${ }^{8}$ Jest to wyraźne nawiązanie do słów z Księgi Rodzaju, wieńczących każdy dzień stwarzania i wiedział Bóg, że to, co uczynił, było dobre - Rdz. 1, 4; 1, 10b; 1, 12b; 1, 18b; 1, 21b; 1, 25b; 1,31 .
} 


\section{„Zilustrować niewysławialne”...}

Stwarzanie wynika bezpośrednio z woli Boskiej. Świadczyć o tym może choćby to, że jeszcze przed rozpoczęciem procesu Bóg w charakterystyczny sposób „kłuje palcami w pustkę”, pokazując, co ma zostać dopiero uczynione (Tamże, s. 22). Stwarzane rzeczy wychodzą zaś - w sensie dosłownym - z rąk Bożych. Niezwykle charakterystyczny jest brak rozgraniczenia pomiędzy stwórczymi gestami Boga a tym, co wskutek tego powstaje. Koza i ryba wydają się wylewać, wypływać czy emanować bezpośrednio z Boga (Tamże, s. 22-23).

\section{Rys. 3. Bóg stwarza zwierzęta}

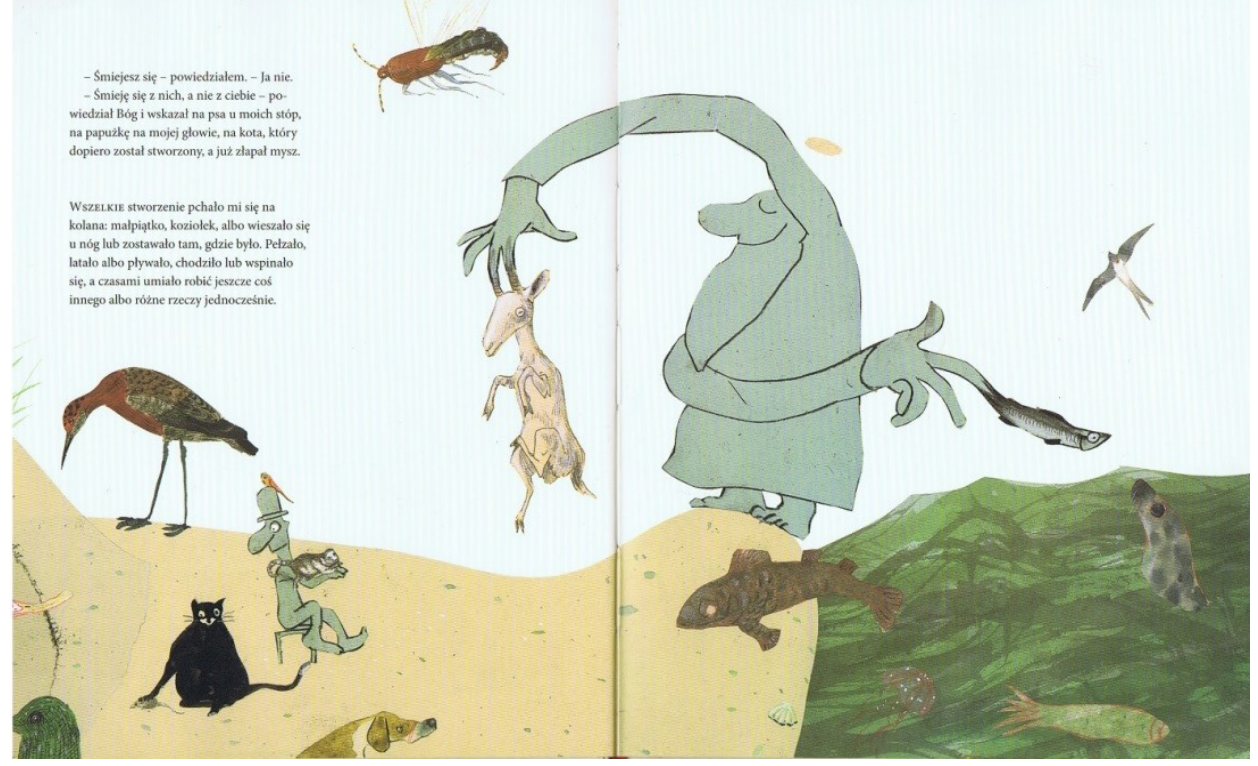

Źródto: Moyeart, Erlbruch, 2005, s. 22-23.

$\mathrm{Na}$ końcu powstaje Ewa. Tak jak Adam, jest ona naga, z podobnie jak w jego przypadku delikatnie, acz wyraźnie zaznaczoną sfera płci (Tamże, s. 28-29). Proces stwórczy kończy się, zgodnie z biblijnym pierwowzorem, odpoczynkiem. Bóg, który „dzisiaj nie stworzył nic” - śpi, obserwowany przez dwoje spośród swych stworzeń (Tamże, s. 30-31).

Innym wartym omówienia zagadnieniem jest sposób obrazowania losu ludzkiego. Bardzo ciekawie kwestię tę przedstawiają Davide Cali (autor) i Serge Bloch (ilustrator) w książce $A$ ja czekam... (Cali \& Bloch, 2013). Życie ludzkie jest tu postrzegane jako nieustanne oczekiwanie na coś, reprezentowane w sferze ikonograficznej w postaci powtarzającego się w różnych modyfikacjach motywu czerwonej włóczki (Tamże, s. 50). Stanowi ona swoistą linię życia (charakterystyczny kolor czerwony), poprzez wspomniane modyfikacje ilustrująca jego złożoność i skomplikowanie. Powracający, przeplatający się 


\section{Alina Brzuska-Kępa, Rafał Kępa}

przez wszystkie obrazy motyw czerwonej wełnianej nici intersemiotycznie wizualizuje metafory, którymi opisuje się życie: nić żywota, życie się plecie, przeciąć, zerwać nić żywota, powiązania życiowe, rodzinne, związki itp.

Początkowo tytułowe „oczekiwania”, składające się na życie człowieka, są dość proste. Małe dziecko czeka na przykład na przyjście gwiazdki (Tamże, s. 10-11). W tym przypadku czerwona włóczka staje się elementem przystrojenia domu: jest zawieszanym na choince łańcuchem bądź girlandami, na których podwieszone zostały pod sufitem ozdoby świąteczne.

Z czasem nasze oczekiwania stają się bardziej skomplikowane - na przykład na miłość. Czerwona włóczka przybiera tu postać splątanej ścieżki, którą przebywa młody człowiek zanim spotka „tę jedyną” (Tamże, s. 12-13). Oczekiwanie „,na to, że ona powie tak” opatrzone jest ilustracją dwojga młodych ludzi w strojach ślubnych, w kościele. Rozwijająca się nić jest tu liną, za pomocą której mężczyzna wciąga swa, najwyraźniej wahająca się, wybrankę do świątyni (Tamże, s. 24-25).

W czasie oczekiwania na dziecko czerwona wełna wykorzystywana jest przez przyszłą mamę do przygotowania ciepłych, wełnianych ubrań dla dziecka (Tamże, s. 27). W niezwykle charakterystyczny, bardzo dosłowny sposób, przedstawione są zaś same narodziny potomka. Na ilustracji widzimy leżącą na łóżku porodowym nagą kobietę. Spomiędzy jej nóg wyjmowane jest dziecko. Czerwona przędza jest tu łączącą ciała dziecka i matki, nie odciętą jeszcze, pępowiną (Tamże, s. 29).

Rys. 4. Narodziny dziecka

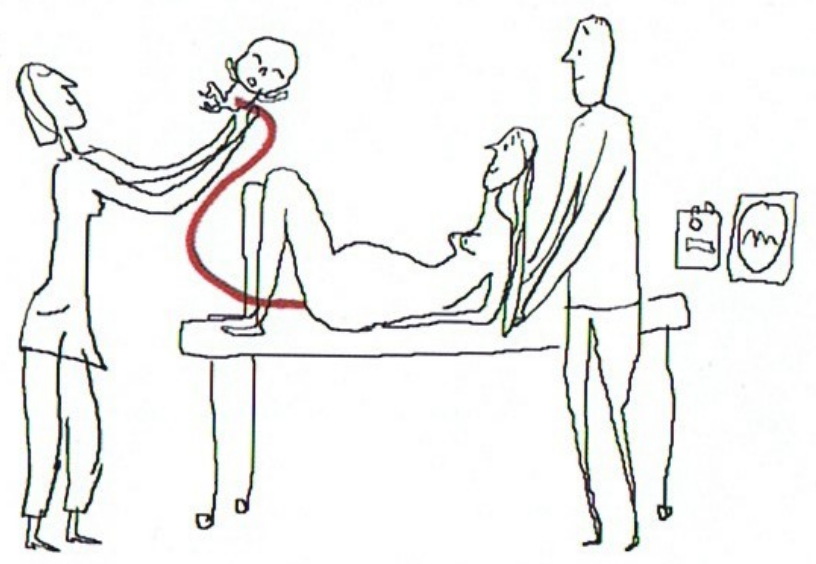

Źródto: Cali \& Bloch, 2013, s. 29. 
Niekiedy czerwona nić kojarzy się z poczuciem bezpieczeństwa, jak choćby w przypadku ilustracji przedstawiajacej oczekiwanie na wakacje, gdzie jest ona lina, za pomoca której ojciec asekuruje dzieci podczas wspólnej wyprawy w góry (Tamże, s. 33). Innym razem staje się symbolem splątania i skomplikowania ludzkich relacji, jak na ilustracji towarzyszacej tekstowi „,[czekam] że ta druga strona powie przepraszam” (Tamże, s. 34). U kresu życia może ona przybrać postać pogrzebowego wieńca, przystrajającego karawan wiozący trumnę na cmentarz (Tamże, s. 43). W tym miejscu następuje jednak swoiste zapętlenie linii życia. Po śmierci, będącej kresem jednego istnienia, czerwona włóczka pojawia się na ostatniej ilustracji (Tamże, s. 49) jako zaczyn nowego: symbolizuje płód w brzuchu ciężarnej kobiety.

Analogiczny motyw - rozwijającej się nici - stosuje Iwona Chmielewska w książce $O$ tych, którzy sie rozwijali (Chmielewska, 2013). Tym razem symbolizuje ona raczej sens życia, a nie ludzki los. Sensu tego upatruje autorka w swoistym samorozwoju, rozumianym jako niesienie pomocy innym. Motywem przewodnim w warstwie ikonograficznej jest tutaj wspomniana już nić. Korpusy niektórych postaci (tych, które niosa pomoc innym) zrobione sa $z$ tekturowych szpulek do nanizania nici, zaś ona sama stanowi element $w$ ten czy inny sposób pomocny. Już na stronach 6-7 widzimy postać doktora Janusza Korczaka (znana z innej książki Chmielewskiej - Pamiętnika Blumki (2011)) wieszającego wyprane dziecięce ubranie, najprawdopodobniej należące do jednego z podopiecznych. Sznurem, którego używa, jest użyczana przez anonimowa „szpulowata” postać nić (Chmielewska, 2013, s. 6-7). W innym miejscu nić oplatająca niosąca pomoc postać służy do podnoszenia ciężarów (Tamże, s. 18), zawiązania snopka zboża (s. 19) czy wyciagania wody ze studni (Tamże, s. 32). Niekiedy towarzyszy zabawie i rekreacji - jest np. dziecięca skakanką (Tamże, s. 22), sznurem do sanek (Tamże, s. 10), służy do zawieszenia huśtawki (Tamże, s. 21). Innym razem jest liną asekuracyjną w górach (Tamże, s. 30). Na dwu obrazach w bezpośredni sposób służy ratowaniu życia: staje się sznurkiem drabinki, po której schodzi z płonącego domu mały chłopiec (Tamże, s. 31), a także liną rzuconą tonącej osobie (Tamże, s. 28-29).

Niesienie pomocy postrzega autorka jako zwykłą ludzką powinność: „Co robili? Zwykle nic wielkiego. To, czego od nich oczekiwano i do czego byli wprost stworzeni" (Tamże, s. 8). Rozumiane jest ono ponadto jako droga do samodoskonalenia i rozwoju: „Dzięki temu mogli się rozwijać i rozwijali się coraz bardziej" (Tamże, s. 10). Niezwykle charakterystyczne jest swoiste spięcie całej książeczki klamrą w postaci wizerunku szpuli nici na jej początku (s. 1) i końcu (na końcowej wyklejce). W pierwszym przypadku szpulka jest „cała”, jeszcze nie używana, w drugim - w znacznym stopniu rozwinięta, zostało na niej już niewiele nici. 


\section{Alina Brzuska-Kępa, Rafał Kępa}

Rys. 5. Ratowanie tonącej osoby

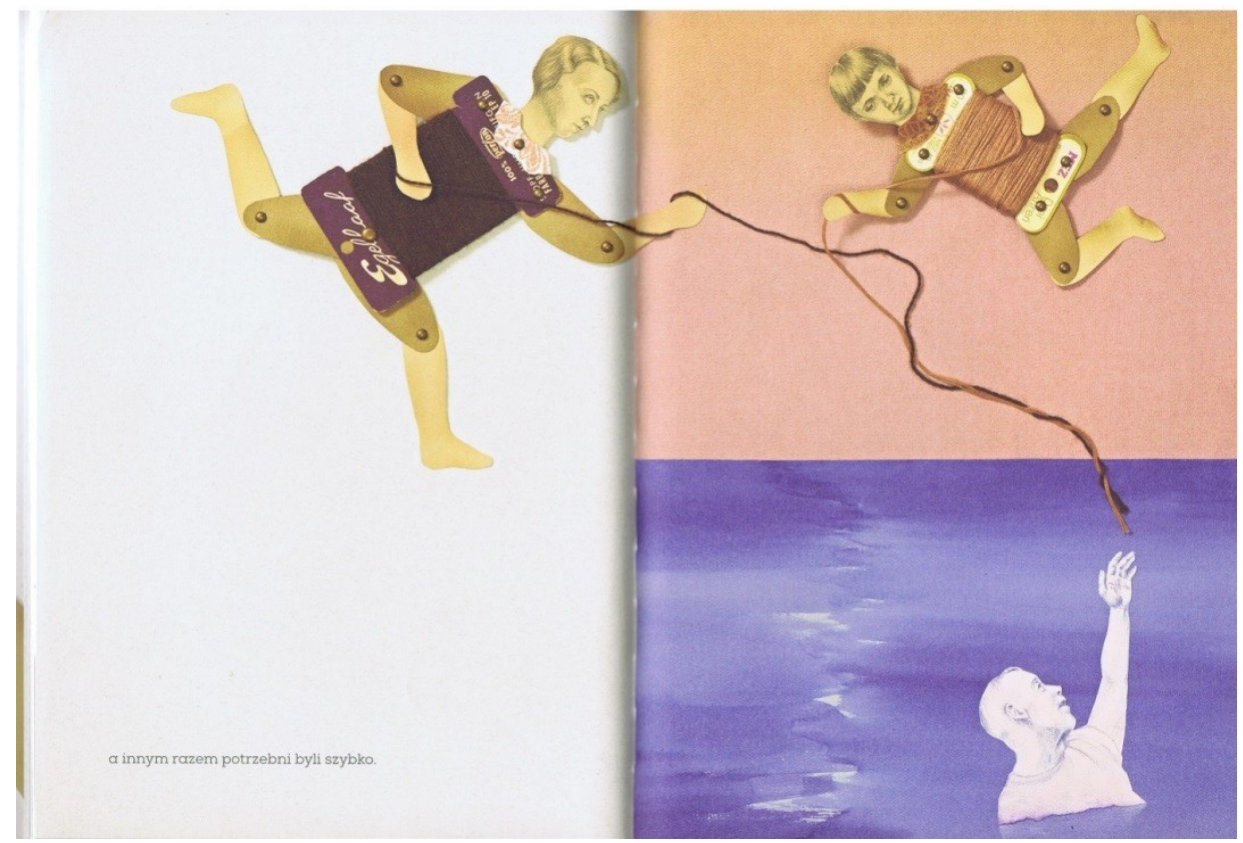

Źródto: Chmielewska, 2013, s. 28-29.

Inną wartą wspomnienia realizacją tematu losu, a zarazem sensu życia, jest Wielkie pytanie autorstwa Wolfa Erlbrucha (Erlbruch, 2006) ${ }^{9}$. Stanowi ona zbiór ilustrowanych odpowiedzi na tytułowe Wielkie Pytanie: „Po co jestem?”. W zależności od wieku, bagażu doświadczeń, wrażliwości, wykonywanego zawodu, a nawet przynależności gatunkowej (odpowiadają bowiem także zwierzęta) przybierają one różne formy. Babcia mówi: „Abym mogła cię rozpieszczać, to jasne!” (Erlbruch, 2006, s. 10-11), grubas: „aby dobrze pojeść” (Tamże, s. 12-13), a słowik: „by śpiewać swoją piosenkę” (Tamże, s. 12-13).

Warto zwrócić uwage na trzy odpowiedzi i towarzyszące im ilustracje. Pierwszej udziela spersonifikowana śmierć. Brzmi ona: „Jesteś po to, by kochać życie" (Tamże, s. 24-25). Motyw śmierci - miłośniczki życia jest bardzo charakterystyczny dla twórczości autora. Pojawił się on także we wspomnianej wcześniej innej jego książce, Gess, śmierí $i$ tulipan. Śmierć, wzywająca tu do umiłowania życia, tam przedstawiona jest jako coś, co życie kończy, jednak w pozytywnym tego słowa znaczeniu. Nie przeciwstawia się życiu, nie jest jego antagonizmem, ale jego istotnym elementem, a zarazem dopełnieniem, czymś, co czyni je kompletnym. Widać to w obu książkach także w warstwie

${ }_{9}$ Erlbruch otrzymał za niemieckie wydanie tej książki główną nagrodę na Targach Książki Dziecięcej w Bolonii w roku 2004. 


\section{„Zilustrować niewysławialne”...}

ikonograficznej. Jak już wspomniano, personifikacja śmierci ma u Erlbrucha pewien rys tradycyjny: jest nim mianowicie wykorzystanie motywu ludzkiego szkieletu. To jednak, jak on wygląda, w żaden sposób nie koresponduje z obrazami znanymi z przedstawień danse macabre. Opisywaliśmy już wizerunek kostuchy w Gesi, śmierci i tulipanie. Jak wygląda ona w Wielkim pytaniu? Pierwszym, co rzuca się w oczy, jest uśmiech, wyraźnie pogodny wyraz „twarzy”, czy - w tym przypadku, jakkolwiek paradoksalnie by to nie zabrzmiało „,czaszki”. Innym elementem całkowicie nielicującym z tradycyjnymi przedstawieniami jest ubiór. W Wielkim pytaniu odziana jest ona w sukienkę w duże, źółte grochy, z gustownym kołnierzykiem. Także ułożenie „ciała” nie wzbudza strachu. Wprawdzie jej ręce ukryte są za plecami, nie ma jednak żadnych podstaw, by domyślać się, że skrywa w nich jakiś złowróżbny atrybut, na przykład kosę (Tamże). Jak się wydaje, do tej „miłośniczki życia” bardziej pasowałby kwiat, z którym przedstawiona jest (w bardzo zresztą podobnej pozie) w Gẹsi, śmierci i tulipanie (Erlbruch, 2008, s. 5).

\section{Rys. 6. Śmierć}

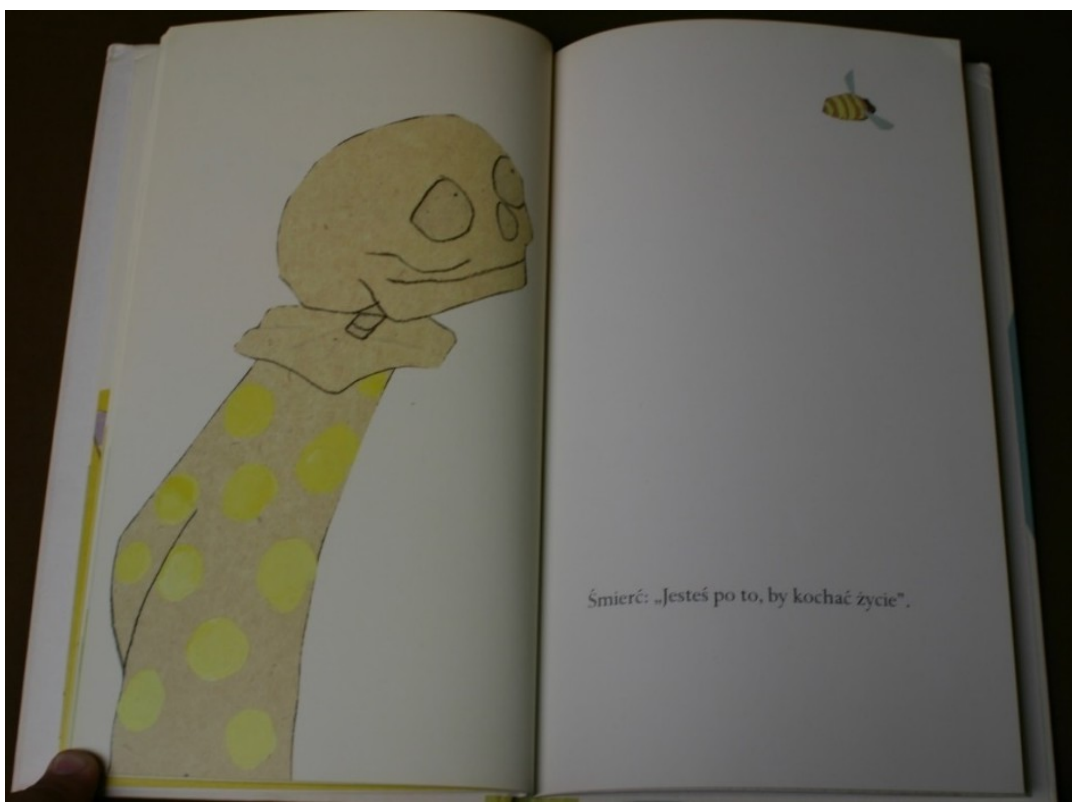

Źródto: Erlbruch, 2006, s. 24-25.

Dwie kolejne odpowiedzi, o których warto wspomnieć, są niezwykle znaczące ze względu na to, że poprzez swoją formę niejako zmieniają charakter i znaczenie Wielkiego Pytania. Początkowo dotyczyły celu istnienia, teraz jego przyczyny. Co charakterystyczne, sa to odpowiedzi udzielane przez osoby 


\section{Alina Brzuska-Kępa, Rafał Kępa}

najbliższe dziecku. Tata mówi: „Jesteś, ponieważ mama i ja bardzo się kochamy" (Erlbruch, 2004, s. 28-29), mama zaś: „Jesteś tutaj, ponieważ kocham cię" (Tamże, s. 44-45). Obrazki im towarzyszące przedstawiają odpowiednio dwoje całujących się ludzi oraz matkę przytulającą do piersi niemowlaka.

Książka kończy się pustą kartą w kratkę, na której dorastający mały czytelnik może zamieszczać swoje - zapewne także w formie rysunkowej - odpowiedzi na Wielkie Pytanie (Tamże, s. 46-48).

Ostatnia publikacja reprezentująca ten zakres tematyczny (losu i sensu życia), o której chcielibyśmy wspomnieć, jest Co za sz̨cz̨ście!/Co za pech! autorstwa Thomasa Hallinga (tekst) i Evy Eriksson (ilustracje) (Halling \& Eriksson, 2010). Los ludzki ujęto w niej jako szereg zwykłych, codziennych zdarzeń, które mogą spotkać każdego człowieka, a które da się interpretować dwojako: jako szczęście lub pech. Publikacja ma postać książki dwustronnej. Czytana „od przodu” przedstawia zdarzenia ze zwykłego dnia życia małej dziewczynki, Amandy. Każde z nich interpretowane jest jako coś dobrego, szczęśliwego. Dziewczynka, korzystając z dobrej pogody, wychodzi na spacer (Tamże, s. 3). „Co za szczęście!” - czytamy - „Gdyby nie to, bardzo by się nudziła" (Tamże, s. 4). Zgodnie z przyjęta konwencja, odwrotna strona ilustracji przedstawia, co mogłoby się wydarzyć, lecz się nie wydarzyło (podtytuł książki to zresztą Opowieść o tym, co sie nie wydarzyto), co zasygnalizowane jest poprzez użycie - inaczej, niż na pełnokolorowym „awersie” - prostej kreski bez kolorów.

Dalej widzimy Amandę, która skręciła w lewo (Tamże, s. 5). „Co za szczęście!” - czytamy. „Gdyby nie to, na głowę spadłaby jej doniczka z kwiatami” (Tamże, s. 6). Co ciekawe, jeśli przeczytamy książeczkę od drugiej strony, znajdziemy w niej dokładnie te same wydarzenia opatrzone krańcowo różną ocena. Dziewczynka wychodzi z domu. „Co za pech!” - czytamy tym razem (Tamże, s. 3) ${ }^{10}$. „Gdyby nie to, bardzo wesoło spędziłaby czas” (Tamże, s. 4). Następnie skręca w lewo (Tamże, s. 5). I tym razem ocena jest negatywna. „Gdyby nie to, dostałaby piękny balon” (Tamże, s. 6).

Obie strony książki spotykają się na wspólnym środku, na którym widzimy śpiąca dziewczynkę (Tamże, s. 22-23). Jednak komentarze do ilustracji są inne w zależności od strony, od której czytamy. Jeśli czytamy od strony „szczęśliwej”, nagle, paradoksalnie, dowiadujemy się, że dziewczynka mia-

\footnotetext{
10 Oczywiście tym razem - także w przypadku kilku kolejnych cytatów - chodzi o numerację liczoną od drugiej, „pechowej” strony. Warto dodać, że w książce, podobnie jak w większość picturebooków, nie wstawiono numerów stron; zazwyczaj powodowane jest to obrazowym charakterem publikacji, w tym przypadku dochodzi dodatkowa trudność w postaci „podwójnego" charakteru opowiadanej historii.
} 
ła... pecha - spotkało ją bowiem wiele szczęśliwych zdarzeń, ona jednak o tym nie wiedziała. $Z$ analogicznego powodu dzień dziewczynki widziany z perspektywy „pecha” ostatecznie oceniony jest jako szczęśliwy. Wprawdzie przez cały dzień prześladował ją pech, ale - na szczęście! - o tym nie wiedziała.

\section{Rys. 7. Szczęście czy pech?}

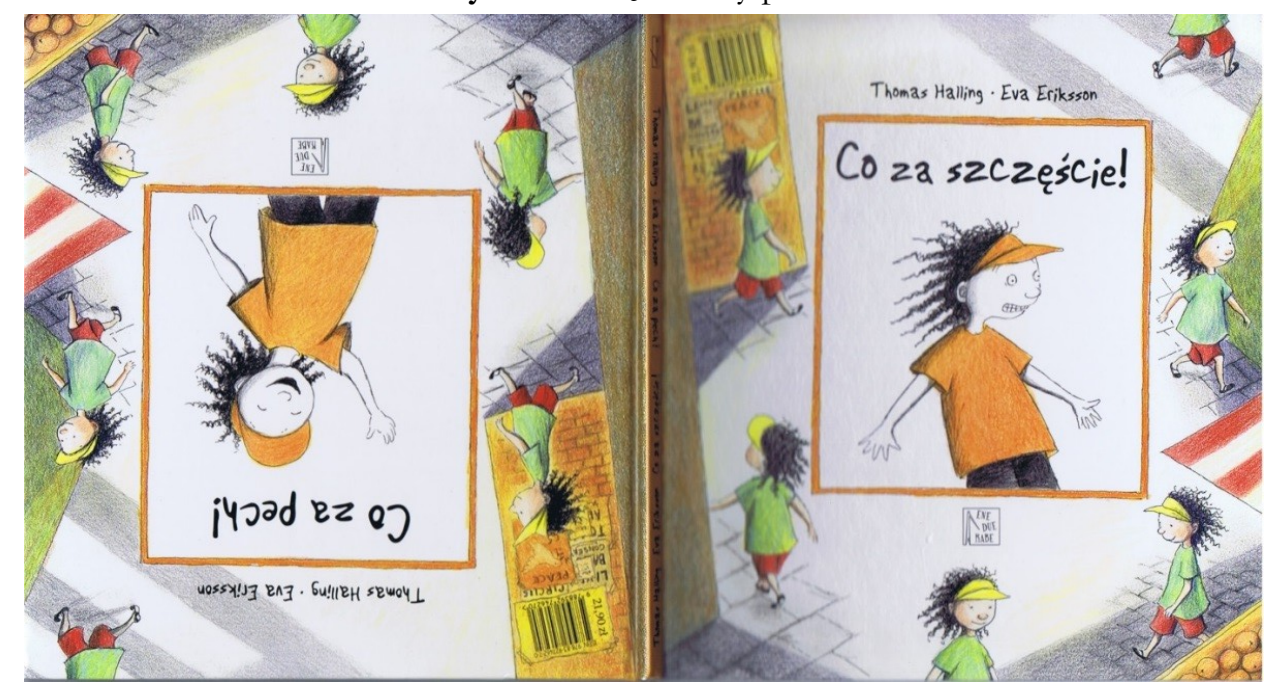

Źródto: Halling \& Eriksson, 2010

Przedstawiając ludzki los w taki właśnie sposób, jako szereg zwykłych, codziennych wydarzeń, którym nadajemy określoną wartość poprzez dokonanie ich oceny, książka T. Hallinga i E. Eriksson wprowadza nas w sferę aksjologii, o której chcielibyśmy na koniec wspomnieć.

Interesująca publikacją poświęconą wartościom, a w szczególności ich relatywnemu charakterowi, jest ksiażka Iwony Chmielewskiej Do połowy pusta, do polowy petna (Chmielewska, 2008). Niestety, książka do dziś nie ukazała się na rynku polskim; prezentowane tu cytaty i ilustracje pochodzą z edycji koreańskiej - autorka jest w tym kraju niezwykle popularna ${ }^{11}$.

Relatywny charakter dokonywanych przez nas ocen doskonale obrazuje już sama okładka. Przedstawia ona szklankę, do której nawiązuje tytuł publikacji. Jest ona wypełniona dokładnie do połowy, co pomaga dostrzec linia przerywana poprowadzona przez niemal całą szerokość obrazu, pokrywająca

11 Prawie wszystkie opublikowane dotąd książki Chmielewskiej mają swoje pierwodruki w wydawnictwach koreańskich, do dziś tylko koreańską edycję mają $\mathrm{m}$. in. Room in the heart, BIUM, Kwak, Young-Kwon, il. Iwona Chmielewska, Wydawnictwo Agibooks, 2009, Gdrie jest moja córka?, Wydawnictwo Nonjang, Seul, Korea, 2011, Moje kroki, Wydawnictwo Nonjang, Korea 2011, Pomysty, wyd. Nonjang, Seul, Korea 2011. 


\section{Alina Brzuska-Kępa, Rafał Kępa}

się z poziomem płynu w szklance. Linia ta wyznacza zarazem oś postrzegania dwóch osób, przy czym jedna skupia wzrok na wypełnionej części naczynia, druga - odwrócona o 180 stopni - na pustej. Patrząc na ten sam przedmiot, postrzegaja go zatem odmiennie (Tamże - okładka).

Rys. 8. Do połowy pusta, do połowy pełna

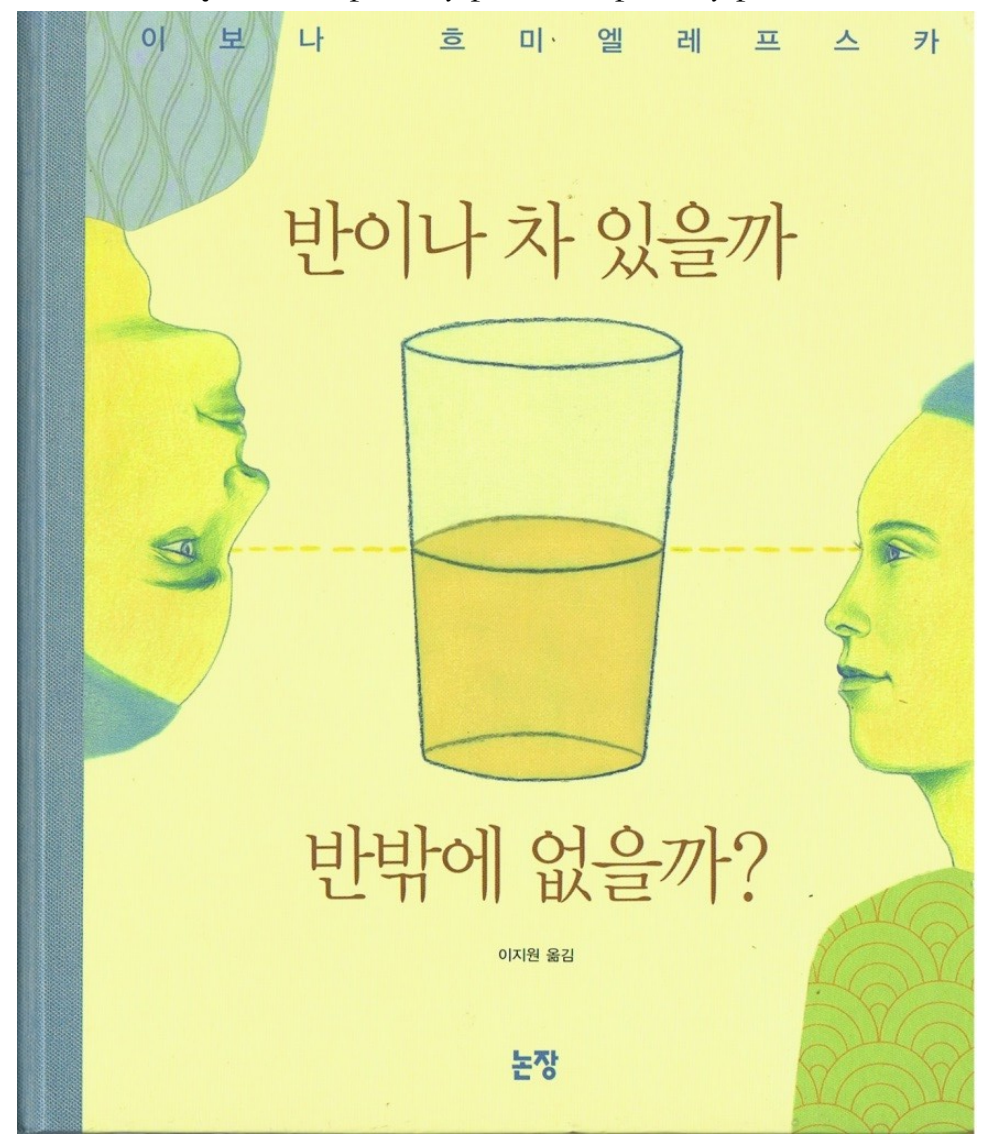

Źródto: Chmielewska, 2008

Całość książki pomyślana jest jako zbiór piętnastu obrazów przedstawiających sytuacje i zdarzenia, które moga być krańcowo różnie oceniane przez ich uczestników. Dla przykładu, na jednym z nich widać mężczyznę wychodzącego na spacer z psem. Wyraz twarzy człowieka świadczy o tym, że dla niego pupil jest piękny. Jednak przechodząca nieopodal starsza, elegancka pani, czująca wyraźny strach przed zwierzęciem, ocenia je zupełnie inaczej. Tekst towarzyszący temu obrazowi skupia się na postrzeganiu piękna: „Co dla jednych jest piękne, dla innych jest brzydkie" (Tamże, s. 6-7). 


\section{„Zilustrować niewysławialne”...}

Czy pokonanie schodów jest łatwe, czy trudne? Z całą pewnością innej odpowiedzi na to pytanie udzieli młoda, zdrowa dziewczyna, która przeskakuje po kilka stopni całkowicie odruchowo, nie myśląc nawet o tym, co robi, innej zaś przykuty do wózka inwalidzkiego chłopiec, dla którego samodzielne wejście na schody jest niemożliwe. Obie te postaci pojawiają się na stronie 20 , na obrazie, któremu towarzyszy tekst: „Co dla jednych jest łatwe, dla innych jest trudne”.

Jedzenie czipsów jest niemal niesłyszalne w gwarze miasta, na przykład tuż obok placu budowy, innym razem zaś jest nieakceptowalnym, uciążliwym hałasem - jeśli spożywa się je na przykład w sali kinowej czy teatralnej. Tym razem autorka dzieli stronę na dwie niezależne połowy, przedstawiające odpowiednio plac budowy oraz salę kinowa. Lączącym te dwa obrazy elementem jest postać jedzącej czipsy dziewczyny. W pierwszym przypadku jej zachowanie pozostaje niezauważone, $\mathrm{w}$ drugim budzi zdecydowany sprzeciw (Tamże, s. 16). Autorka dołącza do obrazu tekst: „To, czego czasem nie słychać, innym razem jest za głośne".

Umyte przez małą dziewczynkę ręce po zabawie na dworze z cała pewnością nie są dostatecznie czyste dla chirurga, który ma właśnie przystapić do operacji. Obie te postaci widzimy, tuż po umyciu rąk, na stronie 8. Tym razem Chmielewska uzupełnia obraz stwierdzeniem: „Co dla jednych jest czyste, dla innych jest brudne".

Kierowca szybkiego, sportowego i zapewne bardzo drogiego samochodu, z pełna prędkością mijającego przejście dla pieszych, patrzy z pogardą na stare, powolne auto, zwalniające i zatrzymujące się przed pasami. Dla niego kierujący starym pojazdem jest zapewne biedny, skoro nie stać go na „coś porządniejszego". Czy nie jest on jednak bogaty dla wkraczającego na przejście bezdomnego, którego jedynym majątkiem jest liche odzienie, przewieszony przez plecy worek i kije, którymi wspiera się, idąc z wyraźnym trudem? (Tamże, s. 10). Autorka nie ma co do tego najmniejszych wattpliwości: „Kto dla jednych jest bogaty, dla innych jest biedny" - pisze.

Co ciekawe, ten sam obraz budzić może jeszcze jedno skojarzenie, równie dobrze pokazujące relatywność ocen. Stary pojazd jest dla kierowcy gnającego sportowego auta za wolny. Z całą pewnością jednak także on jest zdecydowanie za szybki dla wspomnianej wcześniej, wchodzącej na przejście dla pieszych osoby, podpierającej się laskami i poruszającej się z dużym trudem. Gdyby nie uprzejmość kierowcy starego auta, nie miałaby ona szans na przekroczenie jezdni. Do oryginalnego tekstu Chmielewskiej śmiało można by dodać zatem jeszcze jeden: „Co dla jednych jest wolne, dla innych jest szybkie”.

Zdaniem autorki relatywny charakter ma także wiedza. Tata, pokazujący dzieciom rozgwieżdżone niebo i opowiadający o gwiazdach, planetach i konstelacjach, w ich oczach jawi się zapewne jako ktoś, kto wie bardzo wiele. Czym 


\section{Alina Brzuska-Kępa, Rafał Kępa}

jednak jest jego wiedza wobec tej, jaką posiada profesor fizyki, który badaniu gwiazd poświęcił życie? (Tamże, s. 22). Autorka komentuje to w następujący sposób: „Kto według jednych wie wszystko, według innych wie niewiele”.

I najważniejsza opozycja: czas, który dla jednych jest końcem, dla innych jest początkiem - pisze I. Chmielewska, opatrując te słowa obrazem przedstawiającym szpital, gdzie, w sąsiadujących salach, tuż obok siebie leżą człowiek, którego życie właśnie się kończy i kobieta z nowo narodzonym dzieckiem na rękach (Tamże, s. 30). O tym, że faktycznie mamy do czynienia z tą samą chwilą świadczy zachód słońca, widziane przez oba skrzydła okna, w pewien sposób łączącego pokoje, a także znajdująca się u dołu karta z kalendarza, pokazująca datę: poniedziałek, piąty lutego.

Próby zilustrowania, oddania pojęć abstrakcyjnych przy pomocy obrazu, które zaliczyć można do wyodrębnionych przez Romana Jakobsona „tłumaczeń intersemiotycznych", transmutacji, interpretujących znaki językowe za pomoca systemów znaków niejęzykowych (Jakobson, 1963, s. 79), nie sa z cała pewnościa zadaniem prostym. Główną przyczyna jest w tym przypadku ich charakter: są one zazwyczaj bardzo dalekie od codziennego doświadczenia, czasami wręcz całkowicie poza nie wykraczają. Z tego samego względu zresztą równie niełatwe jest ich nazwanie, zwerbalizowanie, zwłaszcza w taki sposób, by powstały przekaz był zrozumiały dla niedoświadczonego, poznającego dopiero świat abstrakcji i odpowiadających im symboli młodego czytelnika. Nie jest to jednak, jak pokazują zaprezentowane tu przykłady, zadanie niewykonalne.

Wydaje się, że w procesie wyjaśniania pojęć abstrakcyjnych szczególnie dobrze sprawdzają się publikacje - jak książki obrazowe - pomyślane są jako jedna, skończona, domknięta pod każdym względem całość, w której obraz nie tyle ilustruje tekst, co w pewien sposób go dopełnia i czyni kompletnym. Co ciekawe, często ich twórca jest zarazem autorem tekstu, jak i ilustratorem, co w znacznym stopniu wpływa na „komplementarność” przekazu. Dodatkowym walorem picturebooków jest także to, że bardzo często posługują się symbolami, alegoriami, metaforami ${ }^{12}$. Mówia zatem, w pewnym sensie, „tym samym językiem", co dotykające abstrakcji i pojęć ogólnych książki filozoficzne. Sa jednak od nich łatwiejsze w odbiorze, dzięki stosowaniu dwu uzupełniających się form przekazu - słowa i obrazu.

\footnotetext{
$12 \mathrm{O}$ książkach obrazkowych posługujących się, bądź będących samymi w sobie swoistą metaforą, alegorią czy symbolem zob. też Brzuska-Kępa (2013).
} 


\section{„Zilustrować niewysławialne"...}

\section{Bibliografia}

Brzuska-Kępa, Alina. (2013). Czytanie obrazu. O myślących książkach Iwony Chmielewskiej. W: M. Antczak, A. Brzuska-Kępa, A. Walczak-Niewiadomska (red. nauk.), Media a çyttelnicy. Studia o popularyzacji czytelnictwa $i$ uczestnictwie kulturowym mtodego pokolenia (s. 303-328). Lódź: Wydaw. Uniwersytetu Lódzkiego.

Cali, Davide \& Bloch, Serge. (2013). A ja czekam... Warszawa: Wydaw. Hokus-Pokus.

Chmielewska, Iwona. (2008). Half full or half empty. Seoul: Nonjang Publishing Co.

Chmielewska, Iwona. (2013). O tych, któray sie rozwijali. Poznań: Media Rodzina.

Cirlot, Juan Eduardo. (2006). Stownik symboli. Kraków: Wydaw. Znak.

Gaarder, Jostein. (1995). Świat Zofii. Warszawa: Jacek Santorski \& CO Agencja Wydawnicza.

Gibert, Bruno. (2011). Niebo. Warszawa: Wytwórnia.

Erlbruch, Wolf. (2006). Wielkie pytanie. Warszawa: Wydaw. Hokus-Pokus.

Erlbruch, Wolf. (2008). Gess, śmieró i tulipan. Warszawa: Wydaw. Hokus-Pokus.

Halling, Thomas \& Eriksson, Eva. (2010). Co za szcześscie!/Co za pech! Katowice: Wydaw. Ene Due Rabe.

Jakobson, Roman. (1963). Essais de linguistique générale. Paris: Les éditions de Minuit.

Kępa, Rafał. (2013). Wielkie pytania małych ludzi. O książkach filozoficznych dla dzieci. W: M. Antczak, A. Brzuska-Kępa, A. Walczak-Niewiadomska (red. nauk.), Media a cåttelnicy. Studia o popularyzacji çytelnictwa $i$ uczestnictwie kulturowym mtodego pokolenia (s. 345-379). Lódź: Wydaw. Uniwersytetu Lódzkiego.

Kiefer, Barbara. (2008). What is a picturebook, anyway? The evolution of form and substance through the postmodern era and beyond. W: L. R. Sipe, S. Pantaleo (red.), Postmodern Picturebooks. Play, Parody, and Self-Referentiality (pp. 9-21). New York-London: Routledge Taylor \& Francis Group.

Lurker, Manfred (1994). Przesłanie symboli w mitach, kulturach i religiach. Kraków: Znak.

Marjańska-Czernik, Maria \& Lipka-Sztarbałło, Krystyna (2008). Nic. Warszawa: Stentor.

Moyeart, Bart, Erlbruch, Wolf. (2005). Stworzenie. Warszawa: Wydaw. Hokus-Pokus.

Murawski, Roman. (2001). Filozofia matematyki: zarys driejów. Warszawa: Wydaw. Naukowe UAM.

Nikolajeva, Maria \& Scott, Carole. (2006). How picturebooks work. New York - London: Routledge Taylor \& Francis Group.

Nodelman, Perry. (1988). Words about pictures: The narrative art of children's picture books. Athens, Georgia: The University of Georgia Press.

Oesterreicher-Mollwo, Marianne. (1992). Leksykon symboli. Warszawa: Wydaw. ROK Corporations SA.

Schuster, Eva. (2002). Taniec śmierci od późnego średniowieça do końca XX wieku. Szczecin: Zamek Ksiaząt Pomorskich.

Tomaszkiewicz, Teresa. (2009). Tłumaczenie piktogramów i ikon. W: A. Kwiatkowska, J. Jarniewicz (red.), Między obrazem a tekstem (s. 49-64). Lódź: Wydaw. Uniwersytetu Łódzkiego.

Wittgenstein, Ludwig. (2016). Traktat logicæno-filozofic₹ny. Warszawa: PWN. 


\title{
'To Illustrate the Unspeakable'. Images in a philosophical picturebooks for children
}

\begin{abstract}
In the last few years on the book market there are more and more philosophical books intended for children, or at least 'philosophising'. A large part of the publication of this type are picturebooks, using an image as the main carrier of information. In this article we will try to answer the question whether the adoption of such a convention - it is constructing content based not only on the text, but also as a significant image (sometimes made by the same person) can be helpful with these 'unspeakable' concepts. How authors and illustrators are trying to present the most general and the most difficult issues? Whether the use of the image would be helpful in this case, or what 'unspeakable' is also 'unillustrateable'?
\end{abstract}

KEYWORDS: picturebook, philosophical book for children, picture, illustration, intersemiotic translation 